\title{
Examining causal relationship among stock market index, crude oil price, exchange rate amid COVID-19 era: an empirical evidence from Indian financial market using VAR model
}

\author{
Maneesh Kumar Pandey $^{1 \otimes}$, Irina G. Sergeeva ${ }^{1}$, Vishal Gudla ${ }^{2}$ \\ ${ }^{1}$ St. Petersburg National Research University \\ of Information Technologies, Mechanics, and Optics, \\ 9 Lomonosova St, Saint Petersburg, 191002, Russian Federation \\ ${ }^{2}$ HSE University, \\ 3 A Kantemirovskaya St, Saint Petersburg, 194100, Russian Federation \\ $\checkmark$ maneeshban@gmail.com
}

\begin{abstract}
The year 2020, so far, has been relentlessly wreaking havoc on the very concept of life and work as we know them. This unprecedented event has been unfolding multiple worst-case scenarios on all fronts of our society and has eclipsed almost every other natural disasters of the modern world and pushing humanity on the verge of tipping point. Up to now, more than 29 million people have been infected and more than 1000 thousand have lost their lives because of COVID-19. So far, this epidemic has not only taken human lives but also snatched the livelihood of millions of people worldwide. Because of this epidemic, the world has been experiencing a kind of regressive mindset, where countries are looking inward, and all kinds of political, social, and economic relations are in a very confused state on account of this ongoing assault on them. Consequently, this epidemic has triggered a high level of skepticism in investors about the certainty of the rapid healing of the social and economic condition which is hindering the quick and healthy recovery of financial markets in most of the pandemic ridden countries of the world. The purpose of this study was to examine the causal relationship among various factors such as crude oils price, exchange rate, and stock market performance during Covid-19 in the context of financial market performance in India. Several methodologies have been applied during this study such Johansen co-integration test, vector autoregression model, and Granger causality test. The results have supported a significant causality among crude oil prices and the exchange rate on stock market performance.
\end{abstract}

Keywords: stock market index, COVID-19, crude oil price, exchange rate VAR model

Article history: received - 28 September 2020; revised - 10 December 2020; accepted 30 January 2021.

For citation: Pandey, M.K., Sergeeva, I.G., \& Gudla, V. (2021). Examining causal relationship among stock market index, crude oil price, exchange rate amid COVID-19 era: An empirical evidence from Indian financial market using VAR model. RUDN Journal of Economics, 29(2), 278-298. http://dx.doi.org/10.22363/2313-2329-2021-29-2-278-298

(C) Pandey M.K., Sergeeva I.G., Gudla V., 2021

(c) () This work is licensed under a Creative Commons Attribution 4.0 International License https://creativecommons.org/licenses/by/4.0/ 


\title{
Взаимосвязь индийского индекса фондового рынка с ценой на нефть и обменным курсом в эпоху COVID-19: эмпирические данные индийского финансового рынка с использованием модели VAR
}

\author{
М.К. Панди ${ }^{1 凶}$, И.Г. Сергеева ${ }^{1}$, В. Гудла ${ }^{2}$ \\ ${ }^{1}$ Санкт-Петербургский национальный исследовательский университет \\ информационных технологий, механики и оптики, \\ Российская Федерация, 191002, Санкт-Петербург, ул. Ломоносова, д. 9 \\ ${ }^{2}$ Наичональный исследовательский университет «Высшая школа экономики», \\ Российская Федерация, 194100, Санкт-Петербург, ул. Кантемировская, д. 3 А \\ $\varangle$ maneeshban@gmail.com
}

\begin{abstract}
Аннотация. Темпы глобального распространения COVID-19 вызывают у инвесторов высокий уровень скептицизма в отношении быстрого возвращения привычных социальных и экономических условий, что препятствует восстановлению финансовых рынков в большинстве стран мира, охваченных пандемией. Цель исследования состояла в изучении причинно-следственной связи между различными факторами, такими как цена на нефть, обменный курс и показатели фондового рынка в эпоху COVID-19, в контексте показателей финансового рынка в Индии. В исследовании использовались тест Йохансена, модель векторной авторегрессии и тест Грейнджера. Результаты подтвердили наличие значительной причинно-следственной связи между ценами на сырую нефть и обменным курсом на показатели фондового рынка.
\end{abstract}

Ключевые слова: индекс фондового рынка, COVID-19, цена на нефть, модель VAR валютного курса

История статьи: поступила в редакцию - 28 сентября 2020 г.; проверена - 10 декабря 2020 г.; принята к публикации - 30 января 2021 г.

Для цитирования: Pandey M.K., Sergeeva I.G., Gudla V. Examining causal relationship among stock market index, crude oil price, exchange rate amid COVID-19 era: an empirical evidence from Indian financial market using VAR model // Вестник Российского университета дружбы народов. Серия: Экономика. 2021. Т. 29. № 2. С. 278-298. http://dx.doi.org/10.22363/2313-2329-2021-29-2-278-298

\section{Introduction}

COVID-19 has become a cliché for everyone across the globe. Since the initial outbreak of this pandemic in Wuhan, China in late December 2019 and early January 2020, this pandemic has incarcerated all kind of social, economic activities in the major parts of the world and the destructive impact of COVID-19 on the global economy and financial markets can be duly reflected in various reports, historical data, and research papers.

The downward spiral in the global financial market began from the last week of February 2020 when almost every stock market reported massive losses, unbeknownst to the world since the 2008 financial crisis. That global meltdown corrected itself slightly in the first week of March, but the signal to investors already out and stock indices, highly volatile with large swings, brought in ultimate mayhem on the floors forcing investors to takeout their funds and resulting 
$9^{\text {th }}$ March became "Black Monday" for the global financial market. Soon after "Black Monday" most European and North American financial markets faced another sharp fall which was more than $9 \%$.

During March 2020, the global financial market witnessed more than $25 \%$ of the slump (Reinicke, 2019). Though April 2020 was less volatile, the global financial market still was under the impression of the COVID-19 crisis and lower crude oil prices. During May 2020, US stocks and crude oil prices rebounded from deeply negative territory.

After rallying by about $25 \%$ during April and May, June was rather modest for the S\&P 500 as the benchmark index rose by about $1.8 \%$ only. Having said it, it still managed to post its third straight monthly gain. Although Dow Jones Industrial Average also followed suit, it would be the reflection of the ground reality. Initial gains were wiped out by a spike in COVID-19 case numbers in many parts of the United States as the month progressed.

July witnessed a strong recovery pattern and lower volatility across major indexes. Despite the unabetted coronavirus case numbers, the S\&P 500 is now in the green for 2020, riding on generally strong earnings from the largest U.S. companies and hopes for an imminent vaccine, most likely by end of 2020 .

The pattern observed so far in the Indian stock market are duly reflected by two major Indian market indices, Nifty and SENSEX, which recorded their worst performance on 23 March 2020 with fall of -12.98 and $-13.15 \%$ respectively, only to be followed by a consistently upward trend with minor corrections.

\section{Literature review}

The literature review section aims to assess the impact of crude oil price, exchange rate dynamics in the currency market, and overall stock market performance in the backdrop of COVID-19, on the financial market performance in India.

The Corona Virus already has tremendous effects on the macroeconomic state of the world with greater impacts to come. Nearly 31 million global cases of COVID-19 have now been recorded. World Health Organization's DirectorGeneral Dr. Tedros Adhanom stressed that behind these statistics, there is a great deal of pain and suffering (Ghebreyesu, 2020). As of mid-September, more than 950,000 thousand people have lost their lives due to COVID-19 as per Johns Hopkins University \& Medicine. In addition to its human cost, the COVID-19 pandemic is impacting economies, employment, education, and health systems. As a result, the world is facing great recession and long-term recovery, which would need coordinated interventions from Governments and provision for effective treatments (Gopinath, 2020).

With per capita income contracting in the largest fraction of countries globally since 1870 , the rate of shrinkage for advanced economies is projected around $7 \%$ in 2020. That weakness will further drag the prospects for emerging market and developing economies, with a projected contraction of $2.5 \%$. World Bank is forecasting global economy to shrink by $5.2 \%$ in year 20202 . With the unprecedented uncertainty, the strength of the recovery is unpredictable and $\mathrm{d}$ economies are being pushed into massive lockdowns, with hope to contain the virus and save lives, but also threatening the worst recession since the Great Depression (Gopinath, 2020). 
The financial services industry in India stares at a crucially small window of opportunity to steer their economic outlook as the country contends with the ongoing coronavirus pandemic. Weaker consumption and a dwindling access to capital will contribute to an overall contraction in real GDP in next couple of years. The implications will be echoed across the industry, from lower borrowing for corporate and consumer to limited capacity for investment and weaker spending. However, Beyond the next couple of years, India's financial sector offers enormous growth potential should sources of risk, such as limited financial inclusion rates and barriers to foreign investment, be addressed.

We begin by providing information about COVID-19 and its impact across the globe and in the context of India. The major impact areas across industries are investment returns and capital valuation around the world. The ongoing economic slowdown triggered by the outbreak will also lead to revenue crunch and a material increase in credit risk and a potential spike in insurance claims covering various commodities and events.

The severity of this pandemic and its contagion effects has crippled value chains for organizations around the world. The supply and demand shock to the global economy is creating feedback loop of fall in consumer spending and a decrease in production potential across multiple industries.

At the Macroeconomic level, although the impact of various stimulative monetary or fiscal policy measures taken by various governments has been somewhat positive on credit markets, they are not able to mitigate the demand and supply shocks in the economy.

The impact of COVID-19 on financial markets worldwide as a result of huge upheaval is evident in most of the recent studies, pretty much in every market. Nuhu A. Sansa (Sansa, 2020) found a significant effect of COVID-19 cases on the performance of the financial markets of China and America. D. Zhang (Zhang et al., 2020) also found a strong significance of COVID-19 on the global financial markets. During the study period, authors found that a higher number of COVID-19 cases were directly proportional to the higher level of risk in the global financial market. Similarly, A.M. Al-Awadhi (Al-Awadhi et al., 2020) reported in their study that COVID-19 effects negatively on the stock market return. A higher number of confirmed cases and a higher number of the death toll due to COVID-19, deteriorate stock market returns significantly. M.A. Estrada (Ruiz Estrada, 2020) indicates that the volatility of oil prices has historically been heavily impacted by pandemics such as COVID-19.

D. Aloui (Aloui et al., 2020) employ the structural VAR model with timevarying coefficients and stochastic volatility to the impact of COVID-19 shocks on the energy futures markets, particularly on crude oil and natural gas S\&P GS Indexes. The findings confirm that energy commodities S\&P GS Indexes respond to COVID-19 shock that varying over time due to fundamentals factors as well as behavioural and psychological factors.

The rapidly developing COVID-19 outbreak poses health risks to employees as well as financial risks and reporting uncertainty to all companies and their stakeholders. All of this translates into significant challenges for society as a whole. 
The UN's International Labour Organization predicts 1.6 billion informal economy workers could suffer "massive damage" to their livelihoods.

The UK, US, Canada, and various European and Asian countries have registered a huge loss in jobs which increases their rate of unemployment. International Monetary Fund Managing Director said "The human costs of the Coronavirus pandemic are already immeasurable and all countries need to work together to protect people and limit the economic damage" (Georgieva, 2020).

\section{Impact of COVID-19 on India}

The economic disruption of the pandemic is proving extensive, leading to a downward revision to real GDP forecasts in 2020 . A contraction of $4.5 \%$ for FY2020/21, followed by a rebound of $6 \%$ in FY2021/22 is on cards for India (Seth, 2020).

The pandemic has serious implications for the financial industry. Data from the Centre of Monitoring Indian Economy show that India's unemployment rate shot up to $23.4 \%$ in April and 23.5\% in May 2020 (Kapoor, 2020). It recovered to $11.0 \%$ in June, but this is still higher than pre-crisis levels. Credit demand is waning due to an uncertain business outlook and lenders are also tightening lending standards in anticipation of an increase in loan delinquencies from September 2020. In the same way, according to R. Pembleton (Pembleton, 2020) forex market disruptions due to COVID-19 are having a profound impact on financial markets and will continue to do so for a long period. In the U.S., the unemployment rate has been mounting to levels higher than those reported during the peak of the great financial crisis and this has caused demand for the dollar to soar as investors seek a safe-haven currency. Hence US dollar appreciates against Indian rupees as well as other currencies.

Similarly, in another latest study done by I. Banerjee (Banerjee et al., 2020) shows that under the combined lockdown period, from March 25 to April 27, a positive correlation between the increasing number of COVID-19 and the higher price of US dollar against Indian rupees which means Indian rupees is being depreciated with rising numbers of a confirmed case. This study focuses on the effect of macroeconomic variables such as crude oil price and currency exchange rate on the stock performance and this study also tries to see the effect of these macroeconomic variables on each other. Moreover, during the present course of the investigation, it would be interesting to examine the effect of stock market performance on these macroeconomic variables as well.

\section{Crude oil}

Like almost all industries, oil \& gas is suffering from reduced demand and operational constraints during the COVID-19 outbreak. The nature of oil and gas and the structure of the market create peculiar issues.

The industry has experienced and will experience a particularly sharp downturn. All aspects such as demand, prices, credit and equity markets, capital spending, dividends, share buybacks as well as the geopolitical equations are impacted. In particular, political will and government appliances are playing a major role in shaping up the outcome of this crisis. 
During the initial phase of the crisis, Saudi Arabia and Russia failed to reach an agreement on output cuts to balance the market. Previously agreed-to production restraint had been abandoned and the market was flooded with oil.

That significantly contributed to the oil price crash but post-agreement between those, the oil has rebounded but it is still around almost half of its price since the COVID-19 outbreak went global. The refining margins have collapsed as well as refinery utilization has dropped.

One report of the U.S bureau of labor statistics, indicates that despite of some apparent benefits to some nations due to falling oil prices, the impact of lower oil prices on oil producing nations is nothing short of disastrous.

Major oil importer countries managed to insulate themselves from this upheaval and they enjoyed low oil prices and strong financial market, whereas major exporter countries suffer a loss when oil prices dipped. Having said that, the cyclical nature of globalization is catching up very fast and as a result, a global slowdown is becoming more of a reality than ever before as demand-supply uncertainty is too complex to form a robust response strategy.

In the light of above, working capital management has become the highest priority. Oil majors like Shell, Total and BP are cutting their capital expenditures and suspending or postponing share buyback programs. Reducing costs, rescheduling debt, consolidation will be the focus in the near-term and winners will be those with most improved balance sheets, lower breakeven prices. Financial necessity might force the strategic consolidation go hand in hand with financial restructuring. Assuming significant lag between capital investment cuts and production tapering, agreement amongst OPEC members on production could change things quickly and dramatically.

Apart for current studies, there are several studies have been done to understand the relationship between financial market performance and crude oil prices.

J. Park and R.A. Ratti in their study established direct connect between oil price shocks and stock markets but the magnitude of swing to positive or negative us depends on several factors. Once of the key deciding criterion, they established was whether the economy was an oil-importer or oil-exporter (Park, Ratti, 2008).

R.-G. Cong revealed that different market conditions of an economy are the main trigger of a positive or negative relationship (Cong et al., 2008). Prof. HuiMing Zhu investigated the relationship between crude oil shocks and stock markets for the OECD and non-OECD panel from January 1995 to December 2009. $\mathrm{He}$ found that crude oil prices and stock prices have a feedback loop mechanism in place that supports each other in the long-run. They concluded that the asymmetric dynamic adjustment behaviour is indeed evident for these countries and it is dependent on country-specific mechanisms by which crude oil prices and disaggregated energy prices affect economic growth and stock prices (Zhu et al., 2010).

Two independent studies, one by K. Jain (Jain, 2013) and the other by P. Strithar (Srithar et al., 2015) studied the impact that oil price volatility had on the economic indicators of India. They considered Gross Domestic Product (GDP), National Stock Exchange of India (NSE), and Inflation from 2003 to 2013 
as variables to run simple regression to analyze the impact that crude oil prices had on them in India. They also corroborated the presence of a positive relationship between crude oil and the Stock market (NSE).

\section{Exchange rate}

There are several current studies during the time of the COVID-19 pandemic era as well as previous studies have been done to examine the effect of the exchange rate on the performance of the stock market.

On account of lacking consensus on the underlying causality in the relationship between stock prices and exchange rates, several studies can be referenced suggesting contrasting notions. On one hand, portfolio balance models of exchange rate determination hypothesize a negative relationship between stock prices and exchange rates, on the other hand, a positive causal relationship between stock prices and exchange is observed where a weakened currency makes local firms more competitive thus leads to an increase in their exports and in turn their stock prices.

A study done by R. Aggarwal examined the influence of exchange rate changes on U.S. stock prices for the period from 1974 to 1978 . They found a positive correlation between exchange rates and stock prices. His study showed that depreciation in the U.S. dollar causes declination in U.S. stock prices and vice versa (Aggarwal, 1981).

Similarly, another study by M.H. Ibrahim examined dynamic interactions among GDP output, price level, money supply, exchange rate, and equity prices for the Malaysian Stock Market by applying cointegration techniques and vector autoregression on time series data. It found a positive effect of exchange rate on stock prices, which supported the findings that local currency appreciation moves the stock prices up and vice versa (Ibrahim, Yusoff, 2001).

However, some earlier studies have found a negative relationship between exchange rate and stock prices in long run, but a positive relationship in the short run. For instance, S. Jawaid investigates the effects of fluctuations in exchange rate and interest rates on stock prices of banking sector in Pakistan. Cointegration results point to a significant causality in exchange rate and short-term interest rate movements and stock prices. On the other hand, a significant positive causality was noted in the exchange rate and interest rate volatilities and stock prices in the short run. Causality analysis confirms bidirectional causality between exchange rate and stock prices (Jawaid, Ul Haq, 2012).

R. Ajayi showed that an upward aggregated domestic stock price pushes domestic currency valuation in short run but in the long-run, stock market growth has a positive effect on domestic currency value. However, currency depreciation has shown a negative knock-on impact on the stock market (Ajayi, Mougoue, 1996).

Another study by K. Kim to examine the relation of industrial production, inflation, exchange rate, and interest rate with the S\&P 500 Index reveals a negative relationship between inflation, exchange rate, and interest rate with the S\&P 500 Index. However, a positive relationship between industrial production and the S\&P 500 index stands out as an outlier (Kim, 2003). 
Based on the above, it can be assumed that there is a weak or no association between stock prices and exchange rates. The events influencing the exchange rates may be different from the drivers behind stock price movements. Some previous research works have corroborated that there is a very weak or no association between stock prices and exchange rates.

B. Solnik examined the impact of several macroeconomic variables including exchange rates, on stock prices. He used monthly data from the U.S., Canada, and seven western European markets. He found that depreciation in native currency showed a positive yet insignificant effect on the U.S. stock market (Solnik, 1987).

L. Rittenberg employed the Granger causality tests to examine the relationship between exchange rate changes and price level changes in Turkey. Since causality tests are sensitive to lag selection, therefore he employed three different specific methods for optimal lag. In all cases, he found that causality relationship from stock price volatility to exchange rate varies but there is no causal relationship from the exchange rate to stock price volatility (Rittenberg, 1993).

Similarly, N. Muhhamad and A. Rasheed examined the impact of exchange rates of Asian countries on their stock market by deploying Vector Autoregression Model to analyze the causal relationship between variables and they found, no longrun or short-run causal relationship between the exchange rate and the Stork market of India and Pakistan (Muhammad et al., 2002). Similar observations were made for Bangladesh and Sri Lanka stock market, however, a bi-directional long-run causality between these variables was identified. The results suggested that in South Asian markets, there is little relation between stock prices and exchange rates, at least in the short run. Investors should not use information obtained from one market to predict the behaviour of the other market.

In another study, $\mathrm{H}$. Zhao by using Vector Autoregression and multivariate generalized autoregressive conditional heteroskedasticity (MGARCH) models found that there was not a stable long-term equilibrium relationship between RMB real effective exchange rate and stock price (Zhao, 2009). S. Suriani also found in their study that there was no relationship existed between exchange rate and stock price, and both the variables are independent of each other (Suriani et al., 2015).

\section{Methodological concept}

As the world is witnessing, the increasing number of COVID-19 cases and its global infestation has been causing an unprecedented adverse effect on every sector of the social and economic environment of the world. This disease is forced to reduce all kinds of activities in the manufacturing sector, transportation sector, service sector, public sector, etc. to its lower level. Hence, a high level of unemployment, a low level of crude oil demand, fluctuations in the exchange rate have been registered in this period.

It is interesting to examine how much these variables have been affected during the COVID-19 pandemic crisis and how these variables affect each other during this economic environment.

In this study statistical software Eviews 10 has been employed to perform statistical analysis. In this study, we have analysed the causal relationship among the National Stock Exchange of India (NSE 50) stock market index, crude oil price, and exchange rate USD/INR. 


\section{The empirical model}

In this study Vector Autoregression Model (VAR) has been deployed to examine the causal relationship among the chosen variables. Vector autoregression is a technique that is used by macroeconomists to examine the joint dynamic behaviour of a collection of variables without requiring strong restrictions of the kind needed to identify underlying structural parameters. It has become a prevalent method of time-series modelling.

Originally Vector Autoregression Model was proposed by Sims in 1980 to address the dynamic relationship among variables and subsequently, VAR models became popular among academicians and researchers as a tool, to handle largescale models in applied macroeconomics.

An empirical model of A VAR system contains a set of $\mathrm{n}$ variables, each of which is expressed as a linear function of $\mathrm{p}$ lags of itself and all of the other $n-1$ variable, plus an error term. A simple VAR model with two variables $a$ and $b$, an order- $p$ VAR would be the two equations:

$$
\begin{aligned}
& a_{t}=\beta_{a 0}+\beta_{a a 1} a_{t-1}+\cdots+\beta_{a a p} a_{t-p}+\beta_{\alpha b 1} b_{t-1}+\cdots+\beta_{a b p} b_{t-p}+u_{t}^{a} \cdots \\
& b_{t}=\beta_{b 0}+\beta_{b a 1} a_{t-1}+\cdots+\beta_{a a p} a_{t-p}+\beta_{b b 1} b_{t-1}+\cdots+\beta_{b b p} b_{t-p}+u_{t}^{b} \cdots
\end{aligned}
$$

\section{Empirical strategy}

This study started by defining the stationary properties of the univariate time series to avoid spurious regressions. Hence, to test for unit roots of the time series variables, the Augmented Dickey-Fuller (ADF) (Dickey, Fuller, 1979) had been performed.

Subsequently, a descriptive statistical analysis was done to examine measures of central tendency, measures of dispersion, and degree of asymmetry in the chosen dataset. Post that, a unit root test was conducted to determine the stationarity of the variables and once a variable had become stationary and found to be integrated of orderl $\{\mathrm{I}(1)\}$ then Johansen cointegration test was employed on the time series data for checking the presence of co-integrating relationship among variables' dataset.

Cointegration analysis helped to identify long-run economic relationships among the variables. While performing the co-integration test, FPE: Final prediction error, AIC: Akaike information criterion, SC: Schwarz information criterion, and the HQ: Hannan-Quinn information criterion criteria had been checked to determine the number of lags in the cointegration test (order of VAR). and then the Trace Statistic and Max-Eigen Statistic had been checked to determine the number of cointegrating vectors present.

If there was no cointegrating relation among variables then Vector Autoregression Model would use. but if there was any cointegration presented among variables then Vector Error Correction (VEC) model would apply. We then estimated the suitable model based on careful analysis of lag length and Johansen cointegration test for all the endogenous variables. Furthermore, a Granger causality test was carried out over the VAR result to assess the short and long-run causality among variables.

Furthermore, the pairwise granger causality test was also applied to understand the pairwise interactions of the selected variables used during the study. 


\section{Data and time series properties}

This study is completely based on secondary data. Daily Data on Indian stock market indicator NSE (NIFTY 50) and Brent crude oil closing prices are taken from the yahoo finance website. On the other hand, daily data of the USD/INR exchange rate from exchangesrates.org.uk website.

\section{Data collection sources}

The data span of March 3, 2020, to September 11, 2020, of this study is data is chosen based on the fact that march was the first and most critical month for the global as well as Indian financial market when COVID-19 was started showing its calamitic effect on the global economy and financial market.

\section{Descriptive statistical analysis}

As evident in Table 1, descriptive statistical analysis of variables reflects a striking deviation in value of measures of central tendency of the variable NSECP and that of INREXCH and BCOCP.

Descriptive statistics of model variables

\begin{tabular}{cccc}
\hline & NSECP & INREXCH & BCOCP \\
\hline Mean & 10143.10 & 75.16042 & 37.64197 \\
Median & 10244.40 & 75.32100 & 40.61000 \\
Maximum & 11647.60 & 76.97000 & 51.69000 \\
Minimum & 7610.250 & 73.00200 & 19.71000 \\
Std. Dev. & 1046.115 & 0.906059 & 7.725986 \\
Skewness & -0.285457 & -0.461522 & -0.635788 \\
Kurtosis & 1.874222 & 2.652853 & 2.332237 \\
Jarque-Bera & 8.431302 & 5.146251 & 10.91571 \\
Probability & 0.014763 & 0.076297 & 0.004263 \\
Sum & 1288174. & 9545.373 & 4780.530 \\
Sum Sq. Dev. & $1.38 \mathrm{E}+08$ & 103.4387 & 7521.047 \\
Observations & 127 & 127 & 127 \\
\hline
\end{tabular}

Source: based on authors' calculations using EViews 11.

The differences between the minimum and maximum value are also quite considerable. for instance, the minimum value of NSECP reported a minimum of 7610.250 and a maximum of 11647.60. Similarly, the minimum value of INREXCH was reported to be 73.00200 with a maximum of 76.97000 . For variable BCOCP, the minimum value was 19.71000 and the maximum value was 51.69000. These results show the diverse nature and magnitude of variables and their impact on each other. Hence, it can be said a fair degree of certainty that most of the variables are not normally distributed, with negative Skewness for all three variables and Kurtosis value range from 1.874222 of for NSECP to 2.652853 for INREXCH.

Time series plots of level variables in Figure also show a similar kind of story produced by descriptive statistical analysis. 


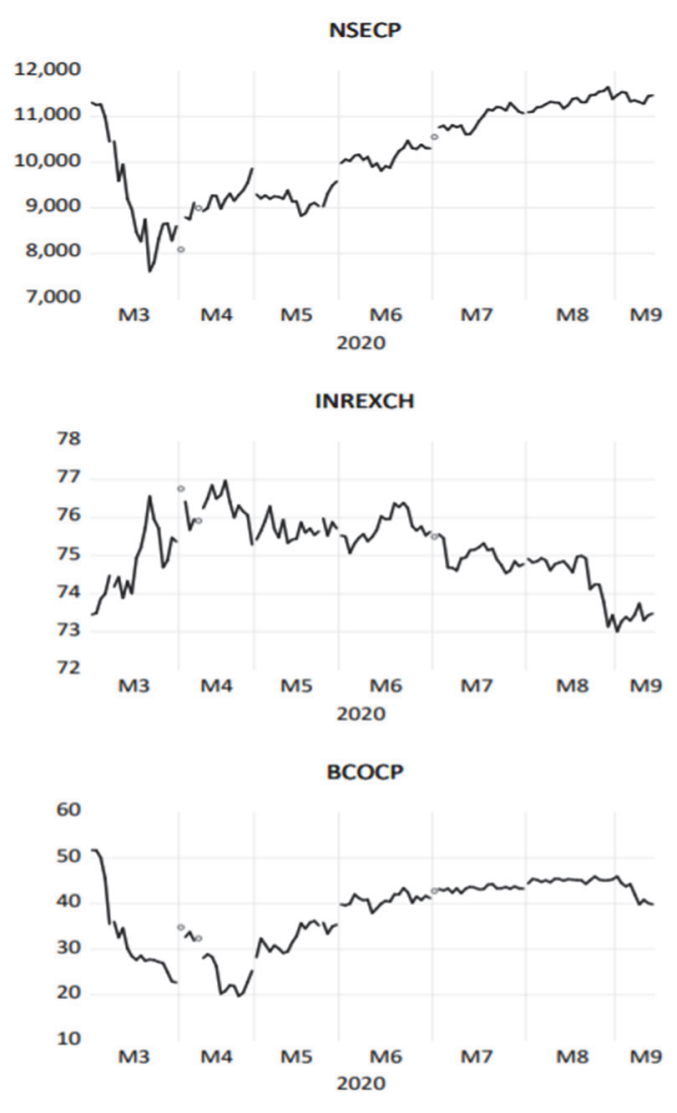

Figure. Graphical representation of variables

Source: based on authors' calculations using EViews 11.

NSECP variable graph representing NSE 50 index has been exhibiting a somewhat upward trend with little fluctuation. However, INREXCH plot shows the depreciation of INR against USD from March 2020 to June 2020 with little fluctuations. However, from June 2020 to September 2020, INR has become a little bit stronger against the USD. In the case of BCOCP, the crude oil price graph exhibits a great dip during March and April 2020 followed by a slow yet gradual upward recovery trend.

\section{Results and discussion}

This section presents both the descriptive and empirical findings of the study.

Unit root test. To check the stationarity of variables' data, the Augmented Dickey-Fuller (ADF) test has been used and the result (Table 2) shows that all three variables are stationary at the first level of differentiation.

Lag length selection. In general, lag length in VAR models is selected using various statistical information criteria, such as Final prediction error, Akaike information criterion, Schwarz information criterion, and Hannan - Quinn information criterion. In this study, optimal lag length 1 has been selected for constructing VAR, as depicted in Table 3. 
Unit root test based on augmented Dickey - Fuller test

\begin{tabular}{ccc}
\hline & Level I (0) & First Difference \\
I (1) & (1)atistics \\
Probability & $\begin{array}{c}\text {-statistics } \\
\text { Probability }\end{array}$ \\
& -0.029321 & -3.463892 \\
NSECP & 0.6711 & 0.0007 \\
INREXCH & -0.288863 & -12.84697 \\
& 0.5800 & 0.0000 \\
BCOCP & -0.908092 & -5.937535 \\
& 0.3211 & 0.0000 \\
\hline
\end{tabular}

Source: based on authors' calculations using EViews 11.

The optimal lag length is 1 with the lowest value produced by AIC, SC, and HQ Information Criteria

\begin{tabular}{|c|c|c|c|c|c|c|}
\hline \multicolumn{7}{|c|}{$\begin{array}{l}\text { VAR Lag Order Selection Criteria } \\
\text { Endogenous variables: NSECP IN } \\
\text { Exogenous variables: C } \\
\text { Date: } 09 / 19 / 20 \text { Time: } 12: 23 \\
\text { Sample: } 3 / 03 / 20209 / 11 / 2020 \\
\text { Included observations: } 121\end{array}$} \\
\hline Lag & LogL & LR & FPE & AIC & SC & HQ \\
\hline 0 & -1472.217 & NA & 7803869. & 24.38376 & 24.45308 & 24.41191 \\
\hline 1 & -1102.023 & 715.9131 & 19931.29* & $18.41361^{*}$ & $18.69087^{*}$ & 18.52621 * \\
\hline 2 & -1095.317 & 12.63574 & 20708.15 & 18.45153 & 18.93675 & 18.64859 \\
\hline 3 & -1089.885 & 9.966209 & 21982.52 & 18.51050 & 19.20367 & 18.79202 \\
\hline 4 & -1086.687 & 5.708587 & 24228.13 & 18.60640 & 19.50753 & 18.97238 \\
\hline 5 & -1076.439 & 17.78564 & 23785.20 & 18.58578 & 19.69485 & 19.03621 \\
\hline 6 & -1065.823 & $17.89836^{*}$ & 23232.14 & 18.55906 & 19.87609 & 19.09396 \\
\hline
\end{tabular}

Note: * indicates lag order selected by the criterion. $L R$ - sequential modified LR test statistic (each test at $5 \%$ level); FPE - final prediction error; $A I C$ - Akaike information criterion; SC - Schwarz information criterion; $H Q$ - Hannan - Quinn information criterion.

Source: based on authors' calculations using EViews 11.

Johansen cointegration test. Johansen cointegration test has been employed to find out the presence of a long-run equilibrium relationship among the variables. An absence of a cointegration relationship among variables suggests that such variables have no long-run equilibrium relationship and in principle, they can wander arbitrarily far away from each other (Jansen, 1991).

From the Johansen cointegration test above, it can be seen from Table 4 that the number of cointegrating relationships implied by trace test and maximum eigenvalue tests differ. The first and second trace statistics are greater than the critical value of the $5 \%$ significance level, which means that the first original null hypothesis and second null hypothesis are rejected. Hence, it can be concluded that two cointegrating relationships are existing among variables.

However, all Max - Eigen statistics' values are lower than the critical value of the 5\% significance level, which means Max - Eigen statistics' values are lower than the critical value of the $5 \%$ significance level which means that all Max Eigen statistics' values are failed to reject the null hypothesis. 
Firstly, as per the cointegration test guideline, trace statistic is showing at least two cointegration whereas Max - Eigen statistic suggests that there is no cointegration relation present among variables. Which means, there is no long-run association among variables.

Johansen cointegration test based on trace statistic and Max - Eigen statistic

\begin{tabular}{|c|c|c|c|c|}
\hline \multicolumn{5}{|c|}{$\begin{array}{l}\text { Date: 09/19/20 Time: 13:09 } \\
\text { Sample (adjusted): } 3 / 05 / 2020 \text { 9/11/2020 } \\
\text { Included observations: } 125 \text { after adjustments } \\
\text { Trend assumption: Linear deterministic trend } \\
\text { Series: NSECP INREXCH BCOCP } \\
\text { Lags interval (in first differences): } 1 \text { to } 1 \\
\text { Unrestricted Cointegration Rank Test (Trace) }\end{array}$} \\
\hline $\begin{array}{l}\text { Hypothesized } \\
\text { No. of CE(s) }\end{array}$ & Eigenvalue & Trace statistic & .05 critical value & Probability** \\
\hline None* & 0.145434 & 35.31276 & 29.79707 & 0.0105 \\
\hline At Most $1^{*}$ & 0.092346 & 15.66757 & 15.49471 & 0.0471 \\
\hline At Most 2* & 0.028048 & 3.556109 & 3.841465 & 0.0593 \\
\hline \multicolumn{5}{|c|}{$\begin{array}{l}\text { Trace test indicates } 2 \text { cointegrating eqn(s) at the } 0.05 \text { level. } \\
\text { Unrestricted Cointegration Rank Test (Maximum Eigenvalue) }\end{array}$} \\
\hline $\begin{array}{l}\text { Hypothesized } \\
\text { No. of CE(s) }\end{array}$ & Eigenvalue & $\begin{array}{l}\text { Max - Eigen } \\
\text { statistic }\end{array}$ & .05 critical value & Probability** \\
\hline None* & 0.145434 & 19.64519 & 21.13162 & 0.0796 \\
\hline At Most 1 & 0.092346 & 12.11146 & 14.26460 & 0.1065 \\
\hline At Most 2 & 0.028048 & 3.556109 & 3.841465 & 0.0593 \\
\hline
\end{tabular}

Max-eigenvalue test indicates no cointegrating eqn(s) at the 0.05 level

Note: * denotes rejection of the hypothesis at the 0.05 level; ** MacKinnon - Haug - Michelis (1999) p-values.

Source: based on authors' calculations using EViews 11.

In other words, during the long-run movement, variables don't move side by side. Secondly, in order to select between the VAR and VEC models, it is also important to consider the lag length. In this study, lag length 1 has been selected and in order to employ the VEC model, reduction of one lag length is required but, in this case, the optimal lag length is 1 and it is not possible to reduce lag length any further. Therefore, in this study Vector Autoregression Model (VAR) has been employed to perform statistical analysis.

Vector Autoregression Model (VAR). In this study VAR model has been employed to examine the relationship between NSE 50 Stock Index Closing Price, Exchange Rate, and Brent Crude oil Prices during the era of the COVID-19 crisis. Empirical Equation of chosen variables for Vector Autoregression Model (VAR) looks as follows:

$$
\begin{aligned}
& N S E C P=\alpha_{1}+\sum_{i=1}^{K} \beta_{i} N S E C P_{t-1}+\sum_{j=1}^{K} \Phi_{j} N R E X C H_{t-j}+\sum_{j=1}^{K} \varphi_{m} B_{C O C P_{t-m}}+u_{1 t} \cdots \\
& I N R E X C H=\alpha_{2}+\sum_{i=1}^{K} \beta_{i} N S E C P_{t-1}+\sum_{j=1}^{K} \Phi_{j} I N R E X C H_{t-j}+\sum_{j=1}^{K} \varphi_{m} B C O C P_{t-m}+u_{2 t} \cdots \\
& B C O P=\alpha_{3}+\sum_{i=1}^{K} \beta_{i} N S E C P_{t-1}+\sum_{j=1}^{K} \Phi_{j} \operatorname{INREXCH}_{t-j}+\sum_{j=1}^{K} \varphi_{m} \text { BCOCP }_{t-m}+u_{3 t} \cdots
\end{aligned}
$$


NSECP stands for NSE 50 Index, INREXCH stands for the currency exchange rate of Indian Rupee (INR) against the U.S. Dollar, BCOCP stands for Brent Crude oil Price:

- the NSE 50 Stock Index Closing Price (NSECP) is a function of its own lagged values and the lagged values of the Exchange Rate (INREXCH) and Brent Crude Oil Prices (BCOCP);

- the Exchange Rate (INREXCH) is a function of its own values and the lagged values of NSE 50 Stock Index Closing Price (NSECP) and Brent Crude Oil Prices (BCOCP);

- the Brent Crude Oil Prices (BCOCP) is a function of its own lagged values and the lagged values of NSE 50 Stock Index Closing Price (NSECP) and Exchange Rate (INREXCH).

\section{Vector Autocorrelation Model (VAM) result}

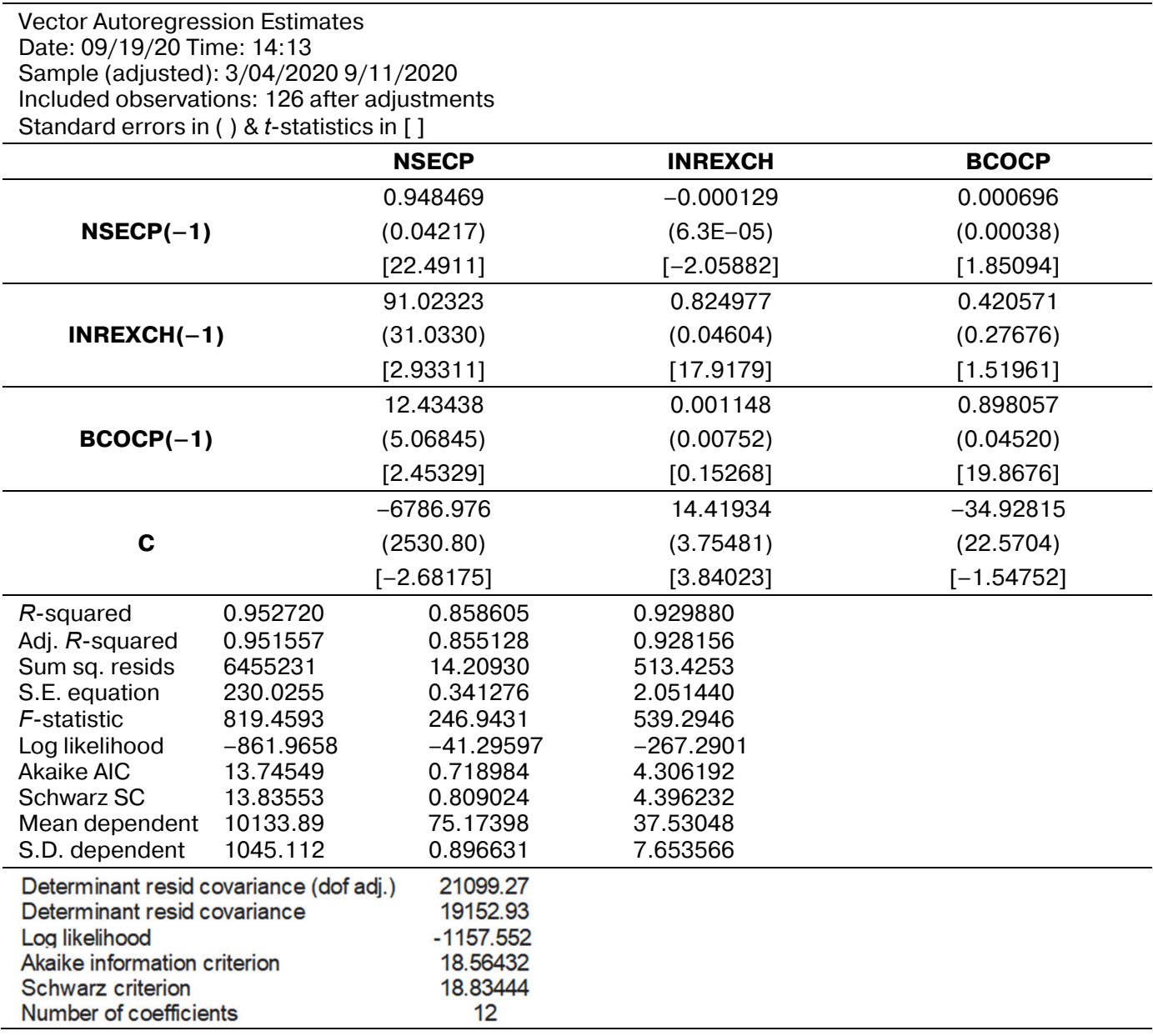

Source: based on authors' calculations using EViews 11.

An analysis of the Vector autoregression model in Table 5 with having 1 lag length $(p=1)$ for each variable has three $(f=3)$ endogenous variables namely NSECP, INREXCH, and BCOCP and the exogenous intercept $\mathrm{C}(d=1)$. Hence, 
there are $(f p+d=4)$ predictors in each of the three equations in this VAR model. Table 5 also shows additional information below the coefficient results.

The first part of the additional information of the VAR result shows standard OLS regression summary statistics at the bottom of the tables for the constructed empirical VAR equation. Moreover, the second part of the additional information consists of summary statistics for the VAR system as a whole. This statistical analysis provides additional information such as determinant of the residual covariance, log-likelihood, and associated information criteria, as well as the number of coefficients.

Table 6 shows the result of the Granger Causality test, which is the next and one of the most important tests in this study.

In the first part of Table 6, Granger Causal's null hypothesis states that the lagged coefficient of INREXCH doesn't cause NSECP and the alternative hypothesis states that the lagged coefficient of INREXCH has a casual effect on NSECP.

By looking at the Chi-Square (8.603129) and probability values $(p=0.0034>.05)$, it is quite clear that the null hypothesis has been rejected in this case which means INREXCH has a causal effect on NSECP. Similarly looking at the Chi-Square $(6.018639)$ and probability values $(p=0.0142>.05)$ for the lagged coefficient of $\mathrm{BCOCP}$, also rejects the null hypothesis that means BCOCP also has a causal effect on NSECP. Hence, the above result shows that both INREXCH and BCOCP have a causal effect on NSECP in the short run.

Table 6

VAR Granger causality/block exogeneity Wald tests

VAR Granger Causality/Block Exogeneity Wald Tests
Date: 09/19/20 Time: $14: 22$
Sample: $3 / 03 / 2020$ 9/11/2020
Included observations: 126

Source: based on authors' calculations using EViews 11.

In the second part of Table 6, the Granger causal's null hypothesis states that the lagged coefficient of NSECP doesn't cause INREXCH and the alternative hypothesis states that the lagged coefficient of NSECP causes effects on NSECP by looking at the Chi-Square (4.238753) and probability values $(p=0.0395>.05)$. 
Hence, it is quite clear that the null hypothesis has been rejected in this case which means NSECP has a causal effect on INREXCH. However, in the case of the lagged coefficient of BCOCP, by looking at the Chi-Square (0.023312) and probability values $(p=0.8786<.05)$. the null hypothesis cannot be rejected which means BCOCP doesn't have a causal effect on INREXCH in the short run.

Estimation of equations using OLS

\begin{tabular}{|c|c|c|c|c|}
\hline \multicolumn{5}{|c|}{$\begin{array}{l}\text { System: UNTITLED } \\
\text { Estimation Method: Least Squares } \\
\text { Date: } 09 / 19 / 20 \text { Time: } 14: 52 \\
\text { Sample: } 3 / 04 / 20209 / 11 / 2020 \\
\text { Included observations: } 126 \\
\text { Total system (balanced) observations } 378\end{array}$} \\
\hline & Coefficient & Std. Error & $t$-statistic & Prob. \\
\hline$C(1)$ & 0.948469 & 0.042171 & 22.49111 & 0.0000 \\
\hline$C(2)$ & 91.02323 & 31.03298 & 2.933113 & 0.0036 \\
\hline$C(3)$ & 12.43438 & 5.068447 & 2.453291 & 0.0146 \\
\hline$C(4)$ & -6786.976 & 2530.797 & -2.681754 & 0.0077 \\
\hline C(5) & -0.000129 & $6.26 \mathrm{E}-05$ & -2.058823 & 0.0402 \\
\hline$C(6)$ & 0.824977 & 0.046042 & 17.91794 & 0.0000 \\
\hline$C(7)$ & 0.001148 & 0.007520 & 0.152683 & 0.8787 \\
\hline$C(8)$ & 14.41934 & 3.754808 & 3.840234 & 0.0001 \\
\hline$C(9)$ & 0.000696 & 0.000376 & 1.850941 & 0.0650 \\
\hline$C(10)$ & 0.420571 & 0.276762 & 1.519612 & 0.1295 \\
\hline$C(11)$ & 0.898057 & 0.045202 & 19.86763 & 0.0000 \\
\hline$C(12)$ & -34.92815 & 22.57044 & -1.547518 & 0.1226 \\
\hline \multicolumn{5}{|c|}{ Determinant residual covariance $\quad 19152.93$} \\
\hline \multicolumn{5}{|c|}{ Equation: NSECP $=\mathrm{C}(1) \star N S E C P(-1)+C(2) \star I N R E X C H(-1)+C(3) \star B C O C P(-1)+C(4)$} \\
\hline \multicolumn{5}{|c|}{ Observations: 126} \\
\hline $\begin{array}{l}R \text {-squared } \\
\text { Adjusted } R \text {-squared } \\
\text { S.E. of regression } \\
\text { Durbin - Watson stat }\end{array}$ & $\begin{array}{l}0.952720 \\
0.951557 \\
230.0255 \\
2.438506 \\
\end{array}$ & \multicolumn{2}{|c|}{$\begin{array}{l}\text { Mean dependent var } \\
\text { S.D. dependent var } \\
\text { Sum squared resid }\end{array}$} & $\begin{array}{l}0133.89 \\
045.112 \\
455231.0\end{array}$ \\
\hline \multicolumn{5}{|c|}{ Equation: INREXCH $=\mathrm{C}(5){ }^{\star} \mathrm{NSECP}(-1)+\mathrm{C}(6){ }^{\star} \operatorname{INREXCH}(-1)+\mathrm{C}(7)^{\star} \mathrm{BCOCP}(-1)+\mathrm{C}(8)$} \\
\hline \multicolumn{5}{|l|}{ Observations: 126} \\
\hline $\begin{array}{l}R \text {-squared } \\
\text { Adjusted } R \text {-squared } \\
\text { S.E. of regression } \\
\text { Durbin - Watson stat }\end{array}$ & $\begin{array}{l}0.858605 \\
0.855128 \\
0.341276 \\
2.238693 \\
\end{array}$ & \multicolumn{2}{|c|}{$\begin{array}{l}\text { Mean dependent var } \\
\text { S.D. dependent var } \\
\text { Sum squared resid }\end{array}$} & \\
\hline \multicolumn{5}{|l|}{ Equation: BCOCP = } \\
\hline \multicolumn{5}{|l|}{ Observations: 126} \\
\hline $\begin{array}{l}R \text {-squared } \\
\text { Adjusted } R \text {-squared } \\
\text { S.E. of regression } \\
\text { Durbin-Watson stat }\end{array}$ & $\begin{array}{l}0.929880 \\
0.928156 \\
2.051440 \\
1.880537\end{array}$ & $\begin{array}{l}\text { Mean dep } \\
\text { S.D. depe } \\
\text { Sum squar }\end{array}$ & $\begin{array}{l}37.5 \\
7.65 \\
513\end{array}$ & \\
\hline
\end{tabular}

Source: based on authors' calculations using EViews 11.

The third part of Table 6, shows that the Chi-square and probability of the lagged coefficient of NSECP is $(3.425983)$ and $(p=0.0642<.05)$, suggest that the null hypothesis cannot be rejected that means the lagged coefficient of NSECP doesn't have a causal effect on the dependent variable BCOCP. Similarly, the lagged coefficient of INREXCH having a Chi-square value (2.309221) and probability $(0.1286<.05)$ shows that the null hypothesis cannot be rejected which 
means INREXCH don't show any causal effect on the dependent variable BCOCP. Hence, it is clear that both NSECP and INREXCH don't have a causal effect on $\mathrm{BCOCP}$ in the short run.

In the next step, the Wald Coefficient test has been performed by formulating an equation for each variable namely NSECP, INREXCH, and BCOCP, showing in Table 7.

The first part of Table 7, shows coefficients, standard error, $t$-statistic, and probability values and the second part of the table shows the equations of NSECP, INREXCH, and BCOCP. Wald test has been deployed to examine whether coefficients have any causal effect on variables.

For the equation of NSE 50 Closing Price (NSECP), it can be seen that the Exchange Rate (INREXCH) and Brent Crude Oil Price (BCOCP) take the coefficient 2 and 3 respectively and with having corresponding probability values (0.0036) and (0.0146) probability values as well which are significant. Hence, the null hypothesis has been rejected in both cases and INREXCH and BCOCP show a causal effect on NSECP.

For the equation of Exchange Rate (INREXCH), it can be seen that the NSE 50 Closing Price (NSECP) takes the coefficient 5 with having corresponding probability value of $(0.0402)$ which is significant. Hence, the null hypothesis has been rejected and, in this case, (NSECP) shows a causal effect on INREXCH. On the other hand (BCOCP) takes coefficient 7 with having a probability value of (0.8787) which is not significant. Therefore, the null hypothesis cannot be rejected. Consequently, (BCOCP) doesn't show a causal effect on (INREXCH).

For the third equation of Brent Crude Oil Price (BCOCP), it can be seen that the NSE 50 Closing Price (NSECP) and Exchange Rate (INREXCH) take the coefficient 9 and 10 respectively and with having corresponding probability values 0.0650 and 0.1295 , which are not significant. Hence, the null hypothesis cannot be rejected in both cases. Therefore, NSECP and INREXCH don't show a causal effect on BCOCP.

In the next step, Pairwise Granger causality tests have been employed for further analysis of the causal relationships among the selected macroeconomic variables. Results in Table 8, shows a bi-directional causal relationship from Exchange Rate (INREXCH) to NSE 50 index (NSECP) and vice versa.

\section{Pairwise Granger causality tests}

\begin{tabular}{|c|c|c|c|c|}
\hline \multicolumn{5}{|c|}{$\begin{array}{l}\text { Pairwise Granger Causality Tests } \\
\text { Date: } 09 / 19 / 20 \text { Time: } 14: 49 \\
\text { Sample: } 3 / 03 / 20209 / 11 / 2020 \\
\text { Lags: } 1 \\
\text { Null Hypothesis: Observations F-statistic Probability Result }\end{array}$} \\
\hline INREXCH does not Granger Cause NSECP & \multirow{2}{*}{126} & 8.73708 & 0.0037 & Reject \\
\hline NSECP does not Granger Cause INREXCH & & 9.49714 & 0.0025 & Reject \\
\hline BCOCP does not Granger Cause NSECP & \multirow{2}{*}{126} & 6.13013 & 0.0146 & Reject \\
\hline NSECP does not Granger Cause BCOCP & & 1.68790 & 0.1963 & Accept \\
\hline BCOCP does not Granger Cause INREXCH & \multirow{2}{*}{126} & 5.07272 & 0.0261 & Reject \\
\hline INREXCH does not Granger Cause BCOCP & & 0.57771 & 0.4487 & Accept \\
\hline
\end{tabular}

Source: based on authors' calculations using EViews 11 . 
Moreover, Table 8 result shows that Brent crude oil price (BCOCP) has a unidirectional causal relationship to NSE 50 index (NSECP) and Exchange Rate (INREXCH). However, NSE 50 index (NSECP) and Exchange Rate (INREXCH) don't show any causal relationship towards Brent crude oil price (BCOCP)

In the next step autocorrelation, the LM test has been performed to check whether the chosen model suffers from autocorrelation problems or not.

VAR residual serial correlation LM tests

\begin{tabular}{|c|c|c|c|c|c|c|}
\hline \multicolumn{7}{|c|}{$\begin{array}{l}\text { VAR Residual Serial Correlation LM Tests } \\
\text { Date: 09/19/20 Time: } 14: 55 \\
\text { Sample: } 3 / 03 / 20209 / 11 / 2020 \\
\text { Included observations: } 126\end{array}$} \\
\hline \multicolumn{7}{|c|}{ Null hypothesis: No serial correlation at lag $h$} \\
\hline Lag & LRE* stat & df & Prob. & Rao F-stat & df & Prob. \\
\hline 1 & 14.22346 & 9 & 0.1146 & 1.600344 & $(9,284.9)$ & 0.1146 \\
\hline \multicolumn{7}{|c|}{ Null hypothesis: No serial correlation at lags 1 to $h$} \\
\hline Lag & 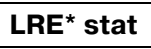 & df & Prob. & Rao F-stat & df & Prob. \\
\hline 1 & 14.22346 & 9 & 0.1146 & 1.600344 & $(9,284.9)$ & 0.1146 \\
\hline
\end{tabular}

Note: * Edgeworth expansion corrected likelihood ratio statistic.

Source: based on authors' calculations using EViews 11.

Table 9 exhibits the result of the autocorrelation LM test. The probability value for lag 1 is 0.1146 . This value is more than .05 and shows that this model does not suffer from serial autocorrelation.

\section{Conclusion}

This study tried to examine the inter-relationship and dependency among exchange rates (INREXCH), Brent crude oil price (BCOCP), and stock market performance (NSECP) in the context of Indian financial market performance during the time of the COVID-19 crisis. These variables are analyzed using the Vector Autoregression (VAR) model, using 1 lag for each variable, with three coefficients. The VAR results show that the exchange rate (INREXCH) and Brent crude oil price (BCOCP) have a significant effect on the stock market performance (NSECP).

The percentage of increase in exchange rates (INREXCH) accounted for an increase of $91.02 \%$ in the stock market index (NSECP). This result supports the previous studies done by R. Aggarwal (1981) and M. Ibrahim (2001) suggesting the positive significant effect of the exchange rate on the stock market performance.

The percentage of increase in Brent crude oil price (BCOCP) accounted for an increase of $12.43 \%$ in the stock market index (NSECP). This result supports the previous studies done by Prof. Hui-Ming Zhu (2010), K. Jain (2013) suggesting the positive significant effect of crude oil price on the stock market performance.

Moreover, according to the Granger causality test, both the exchange rate and crude oil have a causal effect on stock market performance. It can also be seen that stock market performance shows a causal effect on the exchange rate which means both variables have a bi-directional causal relationship with each other. However, the crude oil price has a unidirectional causal effect on stock market performance. 
In light of this study, further research work could be undertaken by employing the firm-level data of individual companies listed on NSE 50 (Nifty) and examining the impact of exchange rates and crude oil prices on their stock performance.

\section{References}

Abu Bakar, N., \& Rosbi, S. (2020). Impact of coronavirus disease 2019 (COVID-19) to equity market and currency exchange rate. IOSR Journal of Economics and Finance, 11(2), 22-31.

Aggarwal, R. (1981). Exchange rates and stock prices: A study of the U.S. capital markets under floating exchange rates. Akron Business and Economic Review, 12, 7-12.

Ajayi, R.A., \& Mougoue, M. (1996). On the dynamic relation between stock prices and exchange rates. Journal of Financial Research, 19(2), 193-207.

Al-Awadhi, A.M., Alsaifi, K., Al-Awadhi, A., \& Alhammadi, S. (2020). Death and contagious infectious diseases: Impact of the COVID-19 virus on stock market returns. Journal of Behavioral and Experimental Finance, 27, 100326. https://doi.org/10.1016/j.jbef.2020.100326

Aloui, D., Goutte, S., Guesmi, K., \& Hchaichi, R. (2020). COVID-19's impact on crude oil and natural gas S\&P GS Indexes. SSRN Electronic Journal. https://doi.org/10.2139/ssrn.3587740

Banerjee, I., Kumar, A., \& Bhattacharyya, R. (2020). Examining the effect of COVID-19 on foreign exchange rate and stock market - an applied insight into the variable effects of lockdown on indian economy. arXiv preprint:2006.14499.

Cong, R.G., Wei, Y.M., Jiao, J.L., \& Fan, Y. (2008). Relationships between oil price shocks and stock market: An empirical analysis from China. Energy Policy, 36(9), 3544-3553.

Dickey, D.A., Jansen, D.W., \& Thornton, D.L. (1994). A primer on cointegration with an application to money and income. Cointegration (pp. 9-45). Palgrave Macmillan, London.

Dickey, D.A., \& Fuller, W.A. (1979). Distribution of the estimators for autoregressive time series with a unit root. Journal of the American Statistical Association, 74(366), 427. https://doi.org/10.2307/2286348

Georgieva, K. (2020). The great lockdown: Worst economic downturn since the great depression. Press release no. 20/98. International Monetary Fund.

Ghebreyesu, A.T. (2020). WHO Director-General's opening remarks at the media briefing on COVID-19 - 18 March 2020. Retrieved January 19, 2021, from https://www.who.int/ director-general/speeches/detail/who-director-general-s-opening-remarks-at-the-mediabriefing-on-covid-19---18-march-2020

Gopinath, G. (2020). New predictions suggest a deeper recession and a slower recovery. World Economic Forum Agenda 2020. Retrieved December 5, 2020, from https://www.weforum.org/agenda/2020/06/imf-lockdown-recession-covid19-coronaviruseconomics-recession/

Ibrahim, M.H., \& Yusoff, S.W. (2001). Macroeconomic variables, exchange rate and stock price: A Malaysian perspective. International Journal of Economics, Management and Accounting, 9(2). Retrieved June 17, 2021, from https://journals.iium.edu.my/ enmjournal/index.php/enmj/article/view/70

Jain, K. (2013). Oil price volatility and its impact on the selected economic indicators in India. International Journal of Management and Social Sciences Research, 2(11).

Jansen, J. (1991). Fitting regression models to ordinal data. Biometrical Journal, 33(7), 807-815. https://doi.org/10.1002/bimj.4710330707

Jawaid, S.T., \& U1 Haq, A. (2012). Effects of interest rate, exchange rate and their volatilities on stock prices: Evidence from banking industry of Pakistan. Theoretical \& Applied Economics, 19(8). 
Kapoor, M. (2020). India's unemployment rate shoots to 23.5\% in April: CMIE. Business Today. Retrieved November 12, 2020, from https://www.businesstoday.in/current/economypolitics/india-unemployment-rate-april-cmie-highest/story/402589.html

Kim, K.H. (2003). Dollar exchange rate and stock price: Evidence from multivariate cointegration and error correction model. Review of Financial Economics, 12(3), 301-313.

Muhammad, N., Rasheed, A., \& Husain, F. (2002). Stock prices and exchange rates: Are they related? Evidence from South Asian countries (with comments). The Pakistan Development Review, 41(4), 535-550.

Murphy, A., Plante, M., \& Yücel, M. (2015). Plunging oil prices: A boost for the US economy, a jolt for Texas. Economic Letter, 10(3), 1-4.

Park, J., \& Ratti, R.A. (2008). Oil price shocks and stock markets in the US and 13 European countries. Energy Economics, 30(5), 2587-2608.

Pembleton, R. (2020). What's the impact on forex trading? Refinitiv. Retrieved November 12, 2020, from https://www.refinitiv.com/perspectives/market-insights/covid-19-whats-theimpact-on-forex-trading/

Reinicke, C. (2019). Goldman Sachs now says US GDP will shrink 24\% next quarter amid the coronavirus pandemic - which would be 2.5 times bigger than any decline in history. Business Insider. Retrieved April 1, 2020, from https://markets.businessinsider.com/news/stocks/us-gdpdrop-record-2q-amid-coronavirus-recession-goldman-sachs-2020-3-1029018308

Rittenberg, L. (1993). Exchange rate policy and price level changes: Casualty tests for Turkey in the post-liberalisation period. The Journal of Development Studies, 29(2), 245-259.

Ruiz Estrada, M.A. (2020). The impact of COVID-19 on the world oil prices. SSRN Electronic Journal. https://doi.org/10.2139/ssrn.3583429

Sansa, N.A. (2020). The impact of the COVID-19 on the financial markets: Evidence from China and USA. Electronic Research Journal of Social Sciences and Humanities, 2(II), 29-39.

Seth, D. (2020). COVID-19 impact: IMF projects Indian economy to contract by $4.5 \%$ in FY21. Special on Coronavirus. Business Standard. Retrieved November 12, 2020, from https://www.business-standard.com/article/economy-policy/imf-cuts-india-growth-forecastto-4-5-for-fy21-6-4-percentage-point-cut-120062401488_1.html

Solnik, B. (1987). Using financial prices to test exchange rate models: A note. The journal of Finance, 42(1), 141-149.

Srithar, P., Bairavi, N., \& Mariselvam, G. (2015). Oil price volatility and its impact on the selected economic indicators in India. International Academic Research Journal of Economics and Finance, 3(4), 10-16.

Suriani, S., Kumar, M.D., Jamil, F., \& Muneer, S. (2015). Impact of exchange rate on stock market. International Journal of Economics and Financial Issues, 5(1S).

World Health Organization. (2020, August 10). COVID-19. Retrieved December 5, 2020, from https:/www.who.int/director-general/speeches/detail/who-director-general-s-openingremarks-at-the-media-briefing-on-covid-19---10-august-2020

Zhang, D., Hu, M., \& Ji, Q. (2020). Financial markets under the global pandemic of COVID-19. Finance Research Letters, 36, 101528. https://doi.org/10.1016/j.frl.2020.101528

Zhao, H. (2010). Dynamic relationship between exchange rate and stock price: Evidence from China. Research in International Business and Finance, 24(2), 103-112.

Zhu, H.-M., Li, S.-F., \& Yu, K. (2011). Crude oil shocks and stock markets: A panel threshold cointegration approach. Energy Economics, 33(5), 987-994. https://doi.org/10.1016/ j.eneco.2011.07.002 


\section{Сведения об авторах / Bio notes}

Панди Мании Кумар, магистрант, факультет экономики и менеджмента, Санкт-Петербургский национальный исследовательский университет информационных технологий, механики и оптики. E-mail: maneeshban@gmail.com

Сергеева Ирина Григорьевна, доктор экономических наук, профессор, факультет технологического менеджмента и инноваций, Санкт-Петербургский национальный исследовательский университет информационных технологий, механики и оптики. E-mail: igsergeeva@gmail.com

Гудла Вишал, магистрант, кафедра менеджмента, Санкт-Петербургская школа экономики и менеджмента, Национальный исследовательский университет «Высшая школа экономики». E-mail: vishalgudla@ gmail.com
Maneesh Kumar Pandey, master student, Department of Economics and Management, St. Petersburg National Research University of Information Technologies, Mechanics, and Optics. E-mail: maneeshban@gmail.com

Irina G. Sergeeva, Doctor of Economics, Professor, Faculty of Technological Management and Innovations, St. Petersburg National Research University of Information Technologies, Mechanics and Optics. E-mail: igsergeeva@gmail.com

Vishal Gudla, master student, Department of Management, St. Petersburg School of Economics and Management, HSE University. E-mail: vishalgudla@gmail.com 